\title{
Adoption of Water-Conserving Irrigation Practices among Row-Crop Growers in Mississippi, USA
}

\author{
Nicolas Quintana-Ashwell ${ }^{1, *} \mathbb{1}$, Drew M. Gholson ${ }^{1}{ }^{1}$, L. Jason Krutz ${ }^{2}$, Christopher G. Henry ${ }^{3}$ \\ and Trey Cooke ${ }^{4}$ \\ 1 National Center for Alluvial Aquifer Research, Mississippi State University, 4006 Old Leland Rd, \\ Leland, MS 38756, USA; drew.gholson@msstate.edu \\ 2 Mississippi Water Resources Research Institute, 885 Stone Blvd, Ballew Hall, Mississippi State University, \\ Leland, MS 38756, USA; j.krutz@msstate.edu \\ 3 Rice Research and Extension Center, University of Arkansas Cooperative Extension Service, \\ Stuttgart, AR 72160, USA; cghenry@uark.edu \\ 4 Delta Farmers Advocating Resource Management, Delta F.A.R.M., Stoneville, MS 38776, USA; \\ trey@deltawildlife.org \\ * Correspondence: n.quintana@msstate.edu; Tel.: +1-662-390-8508
}

Received: 16 June 2020; Accepted: 17 July 2020; Published: 27 July 2020

\begin{abstract}
This article identifies irrigated row-crop farmer factors associated with the adoption of water-conserving practices. The analysis is performed on data from a survey of irrigators in Mississippi. Regression results show that the amount of irrigated area, years of education, perception of a groundwater problem, and participation in conservation programs are positively associated with practice adoption; while number of years farming, growing rice, and pumping cost are negatively associated with adoption. However, not all factors are statistically significant for all practices. Survey results indicate that only a third of growers are aware of groundwater problems at the farm or state level; and this lack of awareness is related to whether farmers noticed a change in the depth to water distance in their irrigation wells. This evidence is consistent with a report to Congress from the Government Accountability Office (GAO) that recommends policies promoting the use of: (1) more efficient irrigation technology and practices and (2) precision agriculture technologies, such as soil moisture sensors and irrigation automation.
\end{abstract}

Keywords: irrigation; groundwater; alluvial aquifer; water conservation adoption; row crops; Mississippi Delta; precision agriculture; Lower Mississippi River Valley

\section{Introduction}

The Mississippi River Valley Alluvial Aquifer (MRVAA) sustains irrigated agriculture in the Mississippi Delta. Almost 22,000 permitted wells [1] withdrawing more than 370 million $\mathrm{m}^{3}$ of water per year [2] continue to reduce the stock of groundwater available in the MRVAA at an unsustainable rate [3]. A shortage of irrigation water would be a critical challenge to agricultural production in the region [4]. To address this threat, researchers, regulators, and conservation agencies promote the adoption of water-conserving practices in irrigated agriculture. However, little is known about what drives growers in Mississippi to adopt water conservation practices that improve irrigation efficiency.

Profitability is a primary concern in any sustainable enterprise. Hence, farmers would adopt new practices that result in higher profits or reduced risks. However, profitable practices are not universally adopted; which suggests there are other factors related to the farmers and their ecosystem that influence their choice of agricultural practices. This implies that the combination of practices adopted and the factors that influence their adoption vary by practice and location [4]. In some cases, 
factors such as farmer age or the practicality of the technology are more important than monetary factors [5]. Recent literature identifies factors likely to be associated with the adoption of certain water management and conservation practices at the state (for example, Nian et al. [4] for Arkansas) and national level [6]. However, no recent study examines the factors driving conservation practice adoption in Mississippi.

This article describes water conservation practices that have the potential to profitably reduce the rate of depletion of the MRVAA and identifies social, economic, and environmental factors associated with the adoption of those practices among irrigators in Mississippi. The adoption of conservation practices and farmer characteristics are identified from a comprehensive survey of irrigators in Mississippi that achieved 148 valid responses. A choice model estimated using probit regression on the dataset identifies which factors have a statistically significant association with each of the practices considered.

The predominant irrigation method in the Delta region of Mississippi is continuous flow furrow irrigation [7] on row-crops. This is a modified gravity irrigation system that employs pipes with holes aligned to deliver the flow of water on the furrows. The system is better suited to the relatively flat Delta area than it would be for other regions. Elevation goes from $62.5 \mathrm{~m}$ above sea level in the northern tip just south of Memphis, TN, to $24.4 \mathrm{~m}$ above sea level at the southern tip in Vicksburg, MS, while the center of the Delta averages an elevation of $38 \mathrm{~m}$ between Greenville and Greenwood. Furthermore, the fields are often precision leveled, which results in less "pooling of water" on the fields and more uniform irrigation. Consequently, the baseline case is a relatively inefficient gravity system in terms of costs and irrigation performance. The conservation practices assessed in this article are modifications, "add-ons", or substitutes to this baseline prevalent system.

There is compelling evidence that even minor modifications to existing irrigation and agronomic practices in the Mid-South USA region can result in noticeable water savings while achieving similar yields at harvest [7-10]. As anticipated, the practices evaluated in those studies and considered here are not universally adopted in the area. Despite the expected profitability of adoption, the costs of these practices occur at the time of adoption while their benefits accrue over time. Consequently, producers may require generous incentives or returns to the cost of investing in conservation practices to adopt them [11] or the assurance of witnessing several years of neighboring farmers employing them.

The adoption of conservation practices in the Delta area of Mississippi is partially driven by regulatory mandate. All wells drilled in the area with a casing diameter of $15 \mathrm{~cm}$ or greater are required to have a permit. The permits must be renewed every five years and require crop producers to file an Acceptable Agricultural Water Efficiency Practices (AAWEP) form. Irrigators must claim to employ a high efficiency irrigation system, such as a sprinkler irrigation system; or claim the use or proposed use of three water conservation practices; see [12] for the permit application and list of acceptable practices.

\subsection{Conservation Practices}

This article considers practices that show potential to profitably conserve irrigation water, are accepted in the AAWEP form, and have been adopted by multiple respondents in the 2016 Survey of Mississippi Irrigators. Although many irrigators may decide on adopting several practices simultaneously, this article analyzes adoption practice by practice in order to maximize the number of valid observations for each case.

Soil Moisture Sensors (SMS) are used in irrigation event decision scheduling to prevent yield-limiting water deficit stress on a given crop. SMS gives producers the knowledge of the moisture within the soil profile to make informed and confident irrigation initiation and termination decisions [8] that typically result in increased irrigation efficiency $[7,13]$.

The simplest and most inexpensive (free) upgrade to the baseline irrigation system is Computerized Hole Selection (CHS). Instead of punching uniform holes in layflat poly-tubing, CHS calculates relatively larger holes for parts of the field with long irrigation runs, while shorter parts of the field receive smaller holes to allow water to uniformly reach the end of the field and minimize 
water runoff [8]. On-farm studies in the Delta area found that CHS achieves water savings of 20 to 25 percent in most situations [14].

"If it can be measured, it can be managed" goes the adage. Pumping flow-meters (meters) are are an important irrigation water management tool compatible with all irrigation systems. Although they do not provide an intrinsic ability to conserve water, they are crucial components, for example, to calculate the optimal size of the holes with CHS [15]. They are also required for cooperator farmers participating in NRCS conservation contracts.

Surge irrigation (surge) allows fields to be divided in two in order to deliver a higher flow rate of water to each half. Water surges down one half of the field until the surge valve flips to deliver water to the other side of the field [8]. The wetting and soaking cycles reduce surface runoff and deep percolation loss while improving water application efficiency by up to 25 percent on the baseline systems with improved infiltration rates documented in sealing silt loam soils [16].

On-Farm Water Storage systems (OFWS) are irrigation water storage structures that are typically designed by NRCS in the Mississippi Delta with the capacity to apply $77 \mathrm{~mm}$ of water per hectare per season and meet irrigation requirements for eight out of 10 years [17]. Depending on seasonal conditions, storage capacity, and farmed area, these systems can completely substitute groundwater pumping in some years. NRCS provides technical and financial assistance to producers interested in building OFWS, but many producers face a high opportunity cost to retire productive land to be used for water storage.

The Tailwater Recovery System (TWS) collects irrigation and storm water runoff on the farm in a reservoir (OFWS). TWS increases the amount of water available to irrigation compared to an OFWS filled only by precipitation. This allows OFWS to occupy a smaller surface area and more hectares to be farmed. NRCS estimates that TWS by itself can reduce groundwater pumping by 25 percent.

Micro-irrigation (micro) is a low pressure, low volume, frequent application of water directly to the plant's root zone [18]. It can increase yields and decrease water use by drastically reducing non-beneficial evaporation and virtually eliminating irrigation water runoff. Micro-irrigation is rarely found in the Delta where the soil types and the water quality make the emitters (i.e., nozzles) prone to clogging.

Center pivot-irrigation (pivot) is a type of irrigation that delivers water through sprinklers that create artificial precipitation and are attached to a wheel-driven frame that rotates radially (the arm pivoting on the center). They are highly configurable for a variety of field and crop requirements. Most center pivot systems in the Delta were installed in the 1980s and designed for cotton [19]. However, the original designs are inappropriate to meet the maximum water demands of corn and soybeans. Consequently, there is both adoption of and migration away from center pivot irrigation in the Delta. Similar to micro-irrigation, the soil types and water quality in the Delta present challenges in the form of nozzle clogging and wheels getting stuck in mud.

Pump timers (timer) are a mechanism to program the time or amount of water at which a pump is shut-off. As it helps to automatically or remotely turn the pumps off, it conserves the excess water that might otherwise be pumped, particularly at night [2]. Timers can be employed across irrigation systems for a variety of crops.

Cover crops (cover) are plants that are typically planted during the off season to cover the soil rather than for the purpose of being harvested. They can help sustain and improve soil health [20], microbial populations, and water infiltration, as well as provide benefits in terms of weed control [21]. This is the only conservation practice being analyzed that is not part of AAWEP.

\subsection{Factors Affecting Conservation Practices}

This article analyzes data from a regional Crop Irrigation Survey that collected 148 valid observations and include data on farmer practices, perceptions and attitudes, and socio-economic status. The factors selected are irrigated area in the operation, Groundwater (GW) use in irrigation, crop choice (rice), number of years farming, years of formal education, whether the farmer perceives a 
GW problem at the farm or state level, average pumping cost in the county of residence, participation in a conservation program, and annual income levels. These factors obtained a sufficient number of valid responses in the sample and were mentioned in two recent comprehensive reviews of the literature $[6,22]$ that identified factors associated with the adoption of agricultural conservation practices or in a recent study of conservation practice adoption in Arkansas [4].

The empirical analysis consists of testing how these factors correlate with adoption of the identified practices. The hypotheses with respect to this association are drawn from the existing literature. Specifically, we draw from a study using similar data in an adjacent area by Nian et al. [4], a comprehensive review of 102 papers in the agricultural conservation practice adoption literature by Prokopy et al. [22], and a 129 page Government Accountability Office report to Congress on Irrigated Agriculture by Pearsons and Morris [6]. In terms of the signs of the regression coefficients, the hypotheses are as follows:

(a) Irrigated area: positive;

(b) (GW) use: positive;

(c) rice farming: negative (most conservation practices are geared towards row-cropping, so their adoption appears less likely for rice farmers.);

(d) years farming: negative;

(e) education: positive;

(f) GW problem: positive;

(g) pumping cost: positive;

(h) conservation program: positive;

(i) cracking soils: negative for surge irrigation, undetermined for other practices; and

(j) income: positive.

\section{Materials and Methods}

\subsection{Data}

The data were from a survey of irrigators in Mississippi conducted by the Survey Research Laboratory at the Social Science Research Center at Mississippi State University [23]. A telephone-based survey secured a total of 148 completed interviews in Mississippi from a total 2216 telephone numbers acquired (861 were disconnected or inaccessible after 10 attempts) with an overall cooperation rate of 27.6 percent. The sample is representative of the Delta area of Mississippi with 131 respondents residing in the area and 3 more in neighboring counties. The survey instrument contained questions on growers' characteristics, cultural practices, irrigation management practices, and perceptions and attitudes regarding groundwater availability.

Except for irrigated area, years of education, and pumping cost, the variables included in the analysis were coded as categorical or indicator (dummy) variables. The pumping cost is calculated as [24]:

$$
p=\theta_{e} p_{e} d,
$$

where $p_{e}$ is the price of the energy source for the power unit, $d$ is depth to water used as a proxy for pumping lift, and $\theta_{e}$ is the amount of energy from source $e$ needed to lift a cubic meter of water a distance of one meter. The distance to water was obtained from the U.S. Geological Survey [25] based on the respondent's claimed county of residence. Average energy prices were obtained from the U.S. Energy Information Administration (EIA).

Cracking soils is the percentage of soils with clay content dominated by smectite. Such soils crack on the surface when a moist soil shrinks due to drying. The data on soil composition is accessible through the USDA-NRCS Websoil survey [26]. This is an important control variable. For example, surge irrigation programs are more difficult to manage in this type of soil because the programming of the alternating cycles is more complicated. The typical program relies on visual cues to switch from 
one side of the field to the next based on the time water takes to reach the tail of the section. In cracking soils, water infiltrates through the cracks, and actual wetting occurs by 3 or more meters ahead of the wetting on the surface. The program is still applicable and carries the same water savings potential, but becomes harder for the farmer to realize.

Number of years of education was calculated based on a question that was originally categorical. The assigned values were as follows: 10 for less than completed high school, 12 for completed H.S., 13 for some college or vocational program, 14 for completed Associate's degree, 16 for completed Bachelor's, 18 for completed Master's, and 20 for more than Master's. This transformation is helpful in the estimation and interpretation of regression results with a sample that is small relative to the number of variables considered.

The variable GW problem is a dummy variable based on the combination of categorical responses to two different questions in the survey: "In your opinion, do you have a groundwater shortage problem on your farm?" and "In your opinion, do you have a groundwater shortage problem in your state?" Lastly, conservation program is a dummy variable based on the combination of responses to four different questions that would have otherwise yield 19 response categories (see Appendix A).

\subsubsection{Choice Model}

There are several ways to motivate the empirical strategy. Due to the nature of the survey and structure of the data, a scenario that allows for irrigators to adopt a single practice or a number of them simultaneously is needed. Hence, a model of individual practice adoption is adequate. An irrigator $i$ adopts a water conservation practice $w$ if the grower expects to receive a greater utility from using the practice $\left(U_{i w}\right)$ than they would not using it $\left(U_{i N g}\right)$. The probability of adopting practice $w$ is the probability that $y_{i w}^{*}=U_{i w}-U_{i N g}>0$ and depends on a vector of $n$ identified factors $X_{i}$. Following Maddala [27], $y_{i}^{*}$ is a latent, unobservable variable defined by the regression relationship:

$$
y_{i w}^{*}=\beta^{\prime} X_{i}+u_{i}
$$

where $u_{i}$ is the error term. The variable that is actually observed is whether a practice is adopted $(y=1)$ or not $(y=0)$.

From these relationships, the probability that any given practice $w$ is adopted can be estimated using probit with the assumption that $u_{i}$ follows a normal distribution:

$$
\operatorname{Pr}\left(y_{w}=1\right)=\operatorname{Pr}\left(\sum_{j} \beta_{j w} X_{j}>0\right)=\Phi\left(\sum_{j} \beta_{j w} X_{j}\right)
$$

where $\Phi(\cdot)$ is the cumulative normal distribution function.

To predict the effect a change in the value of a variable would have on the probability of adopting a given practice, the marginal effects are calculated as:

$$
\frac{\partial}{\partial x_{i k}} \Phi\left(X_{i}^{\prime} \beta\right)=\phi\left(X_{i}^{\prime} \beta\right) \beta_{k}
$$

where $\phi(\cdot)$ is the normal probability density function. This marginal effect is denoted as $d y / d x$ in the results.

\section{Results and Discussion}

\subsection{The Sample}

The survey instrument contained questions on growers' characteristics, cultural practices, irrigation management practices, and perceptions and attitudes regarding groundwater availability. Table 1 summarizes the information gathered on growers' land tenure, education, and income. 
Responses were considered to be representative of irrigators operating in the Delta because 88.5 percent of respondents resided in that area and additional respondents lived in neighboring counties. Cracking soils were present in 83.1 percent of the counties where irrigators claimed residence with an average of 27.6 percent of soils classified as cracking.

Table 1. Summary statistics of farmer characteristics from an irrigation survey conducted in the Mississippi Delta in 2016.

\begin{tabular}{lrr}
\hline Farmer Characteristics & N & \% \\
\hline Delta & 131 & 88.5 \\
Cracking soil & 123 & 83.1 \\
\multicolumn{1}{c}{ Avg. percentage } & & 27.6 \\
Operator & 31 & 20.9 \\
Landowner and operator & 117 & 79.1 \\
\hline Education: & & \\
Less than high school & 5 & 3.4 \\
Completed high school or GED & 23 & 15.5 \\
Some college & 22 & 14.9 \\
Completed Associate's & 18 & 12.2 \\
Completed Bachelor's & 66 & 44.6 \\
Completed Master's & 11 & 7.4 \\
Beyond Master's & 2 & 1.4 \\
Agriculture-related & 63 & 42.6 \\
\hline Income per year: & & \\
Less than USD50,000 & 13 & 8.7 \\
USD50,000 to USD100,000 & 41 & 27.7 \\
USD100,000 to USD150,000 & 17 & 11.5 \\
USD150,000 to USD200,000 & 9 & 6.1 \\
USD200,000 to USD250,000 & 6 & 4.1 \\
USD250,000 to USD300,000 & 5 & 3.4 \\
More than USD300,000 & 10 & 6.8 \\
Unsure or no response & 47 & 31.7 \\
\hline
\end{tabular}

Almost 80 percent of respondents were land-owner operators, and the remaining growers were operators only. Nearly two-thirds of the farmers completed a post-secondary degree (65.6 percent), and 42.6 percent of respondents indicated that part of their formal education was related to agriculture.

Growers also identified the range of income they had achieved the previous year. A total of 101 valid responses were recorded with 31.7 percent of respondents refusing to provide an answer or being unsure with respect to which income bracket they belonged. Amongst the valid responses, fifty-three-point-five percent of farmers claimed an annual income of less than USD100,000. The median income in the sample was between USD75,000 and USD100,000 per year.

Income level is expected to be positively correlated with the adoption of conservation practices [4,6]. Also, the level of farmer education positively influences the adoption of irrigation-related precision agriculture practices [6].

\subsubsection{Farming Practices}

Data on growers' agricultural experience and practices are summarized in Table 2. In terms of farming experience, respondents represented a wide range of experience, from as little as three years to as much as 80 years of farming experience. Every measure indicated that these were seasoned farmers. On average, growers had 28 years of farming experience with a median and mode of 29 and 30 years of experience, respectively. More than 84 percent of farmers had 10 years or more of farming experience. Approximately two-thirds of the sample were farmers with more than 20 years of experience. The number of years farming was expected to be negatively associated with the adoption of agricultural innovations. 
Table 2. Summary statistics of cultural practices.

\begin{tabular}{|c|c|c|c|c|c|c|}
\hline & $\mathbf{N}$ & $\%$ & Min & Max & Mean & Std. Deviation \\
\hline \multirow[t]{2}{*}{ Years farming } & 148 & 100 & 3 & 80 & 28.03 & 14.761 \\
\hline & \multicolumn{6}{|c|}{ (Min, Max, and Mean in ha) } \\
\hline Irrigated area (ha, all) & 148 & 100.0 & 0 & 6070 & 896 & 1007 \\
\hline \multicolumn{7}{|l|}{ Irrigated crops } \\
\hline Corn & 106 & 71.6 & 2.02 & 1821 & 305 & 337.7 \\
\hline Cotton & 49 & 33.1 & 18.1 & 2833 & 490 & 546.7 \\
\hline Rice & 41 & 27.7 & 32.4 & 1558 & 373 & 407.2 \\
\hline Soybeans & 131 & 88.5 & 27.1 & 3804 & 671 & 700.2 \\
\hline Cover crop & 45 & 30.4 & 4.05 & 1335 & - & - \\
\hline Land leveling & 124 & 83.8 & & & & \\
\hline Zero grade & 26 & 17.6 & 2.02 & 971 & 177 & 239.6 \\
\hline Precision grade & 116 & 78.4 & 3.24 & 4654 & 733 & 848.5 \\
\hline Warped or OptiSurface & 33 & 22.3 & 10.12 & 1619 & 266 & 385.9 \\
\hline Not leveled & 76 & 51.4 & 4.05 & 1714 & 202 & 240.3 \\
\hline Conservation programs & 111 & 75 & & & & \\
\hline CRP & 58 & 39.2 & - & - & - & - \\
\hline EQIP & 87 & 58.8 & - & - & - & - \\
\hline RCPP & 14 & 9.5 & - & - & - & - \\
\hline CSP & 31 & 20.9 & - & - & - & - \\
\hline NRCS & 8 & 5.4 & - & - & - & - \\
\hline Other & 8 & 5.4 & - & - & - & - \\
\hline
\end{tabular}

Note: CRP is NRCS Conservation Reserve Program; EQIP is NRCS Environmental Quality Incentives Program; RCPP is NRCS Regional Conservation Partnership Program; CSP is NRCS Conservation Stewardship Program; NRCS is USDA Natural Resources Conservation Service unspecified program.

The size of the farming operation is an important factor in deciding the adoption of agricultural practices in general. The average operation involved 896 ha of irrigated farmland with a median of 567 ha and as much as 6070 irrigated ha. More than three-fourths of the responding growers operated 1133 ha or less. Hence, the number of irrigated hectares was expected to be positively correlated with the adoption of conservation practices.

Crop choice is oftentimes associated with the choice of irrigation technology [28,29]. The largest number of growers reported producing irrigated soybeans $(n=131)$, which occupied the largest cultivated area among the irrigated crops reported: 671 ha on average and as much as 3804 ha. Irrigated corn was the second most popular crop choice with 106 farmers reporting an average of 305 ha and as much as 1821 ha of irrigated farmland dedicated to that crop. Cotton is a traditional crop in the Delta region of Mississippi. About a third of the respondents grew cotton with irrigation dedicating an average of $490 \mathrm{ha}$ and as much as 2833 ha to its production. These are typically row-crops that employ the same or similar irrigation setups when the fields are prepared for furrow irrigation.

Kebede et al. [2] reported that irrigated rice consumes more water than any other crop in the region. Growers in this sample reported an average of 373 ha of irrigated rice farmland with as much as 1558 ha of rice under irrigation. Rice production was expected to be negatively correlated with the conservation practices considered in this article, which were better suited for row-crop irrigation.

Cover crops are typically not harvested. Consequently, these crops were not considered as part of crop choices, but rather as a conservation practice in this article. Nearly a third (30.1 percent) of growers in the sample claimed to plant cover crops. Responses to the survey varied widely in terms of crop and area matching. Wheat and radishes received the highest reported area of 1335 ha, while the least was reported for Asian mustard greens ( $4 \mathrm{ha}$ ). The adoption of this practice was tested against the identified explanatory factors.

Land leveling is a relatively common practice in the area with 84 percent of growers reporting having at least a part of their fields land-leveled in some way. It is also no surprise that 51.4 percent of 
the participating growers reported that some fields were not leveled because the Delta in Mississippi is unusually flat. Precision grade was the most common land leveling method with 78 percent of growers employing it on an average of 733 ha and in up to 4654 ha of their operation.

Awareness and participation in conservation programs were expected to positively influence the adoption of irrigation water conservation practices $[4,6]$. Three-fourths of the growers claimed participation in a conservation program. The program most commonly cited was the NRCS Environmental Quality Incentives Program (EQIP) with 59 percent participation.

\subsubsection{Irrigation and Water Conservation Practices}

Grower irrigation practices are summarized in Table 3. Groundwater was the principal source of water for irrigation with 93 percent of respondents identifying it as a source. On average, eight-hundred eighty-nine hectares were irrigated with groundwater with a maximum of 4856 ha relying on that source for irrigation. Surface water was also employed for irrigation including streams and bayous, which are the source for 178 ha on average. The surface sources can also be complemented with OFWS, 11.5 percent of responses, and TWS in 14.2 percent of responses. Some growers built OFWS and TWS capable of fully supplying the irrigation water needs for some of their fields. Producers relying on groundwater from a depletable aquifer were expected to be more inclined to adopt water conservation practices.

The predominant irrigation practice was furrow irrigation for row-crops, which was employed by 86 percent of respondents on an average of 823 ha. Practices that improve the performance of furrow irrigation are deep tilling, employed by 71 percent of the respondents, computerized hole selection (CHS), adopted by 59 percent of growers, and surge irrigation, adopted by 24 percent of farmers in the sample. The last two are considered water-conserving practices for which we sought to find determining adoption factors. Irrigation systems with higher application efficiency are also considered water conservation practices. Micro irrigation was very rare with only 3.4 percent of respondents employing it on an average of 65 ha; while center pivot sprinkler use was more widespread with 60 percent of respondents having used it on an average of 370 ha.

Irrigation scheduling is a crucial component of irrigation water management. The use of Soil Moisture Sensors (SMS) for scheduling has the potential to save as much as 50 percent of total water applied [30]. Agronomic studies in the area showed that SMS could help improve water use efficiency in furrow irrigated soybeans [7] and corn [10] by reducing water use without reductions in yields when compared to conventional farmer-managed scheduling.

Flow-meters at the irrigation wells are another important management tool. Nearly 70 percent of participant growers owned them. A voluntary metering program in Mississippi encourages their use, and participation in NRCS incentive programs makes participation in that program mandatory for their cooperators. Another pump accessory is the pump timer, which allows the irrigation events to be started or stopped automatically. Almost 44 percent of respondents employed pump timers on an average of 11 pumps.

Finally, the energy source for the pump power units varied with most growers having more than one type of energy source. Electricity was the most common energy source with 85 percent of farmers claiming it. Diesel was the second most common source with almost 80 percent of respondents using it. The energy source mix is important in calculating irrigation pumping costs. The average cost of pumping was estimated at USD 0.0538 per megaliter. 
Table 3. Summary statistics of irrigation practices.

\begin{tabular}{|c|c|c|c|c|c|c|}
\hline & $\mathbf{N}$ & $\%$ & Min (ha) & Max (ha) & Mean (ha) & Std. Dev. \\
\hline \multicolumn{7}{|l|}{ Irrigation by source of water } \\
\hline Groundwater & 137 & 92.6 & 2.83 & 4856 & 889 & 909 \\
\hline Stream or bayou & 39 & 26.4 & 7.69 & 599 & 178 & 142 \\
\hline Stream or bayou and OFWS & 17 & 11.5 & 2.02 & 977 & 182 & 253 \\
\hline Stream or bayou and TWS & 21 & 14.2 & 16.2 & 707 & 178 & 185 \\
\hline No outside source w/OFWS/TWS & 16 & 10.8 & 4.45 & 304 & 81 & 84 \\
\hline \multicolumn{7}{|l|}{ Irrigation by practice } \\
\hline Flood (row-crops) & 69 & 46.6 & 6.07 & 4047 & 737 & 939 \\
\hline Furrow (row-crops) & 127 & 85.8 & 1.62 & 4452 & 823 & 942 \\
\hline Deep till (furrow) & 104 & 70.7 & 1.62 & 2428 & 512 & 522 \\
\hline Computerized hole selection & 87 & 58.8 & 1.62 & 3462 & 734 & 706 \\
\hline Surge & 35 & 23.6 & 12.1 & 607 & 140 & 146 \\
\hline Border (row-crops) & 26 & 17.6 & 10.1 & 769 & 158 & 274 \\
\hline Micro (row-crops) & 5 & 3.4 & 2.02 & 223 & 65 & 106 \\
\hline Pivot (row-crops) & 88 & 59.5 & 2.43 & 2428 & 370 & 391 \\
\hline \multicolumn{7}{|l|}{ Irrigation scheduling } \\
\hline Soil moisture sensors & 72 & 48.6 & 0.4 & 6070 & 554 & 1027 \\
\hline Visual crop stress & 103 & 69.6 & - & - & - & - \\
\hline Computerized scheduling & 5 & 3.4 & 80.9 & 243 & 146 & 102 \\
\hline Routine & 29 & 19.6 & - & - & - & - \\
\hline Probe/feel & 27 & 18.2 & - & - & - & - \\
\hline ET or Atmometer & 4 & 2.7 & 0 & 202 & 99 & 84 \\
\hline \multirow[t]{2}{*}{ Watch other farmer } & 6 & 4.1 & - & - & - & - \\
\hline & & & Min (units) & Max (units) & Mean (units) & Std. Dev. \\
\hline Irrigation pumps & 146 & 98.6 & 1 & 120 & 21 & 24.0 \\
\hline Pump timers & 65 & 43.9 & 1 & 90 & 11 & 16.6 \\
\hline Flow-meters & 103 & 69.6 & 1 & 46 & 8 & 7.9 \\
\hline \multicolumn{7}{|l|}{ Power unit } \\
\hline Electric & 126 & 85.1 & 1 & 80 & 11 & 14.8 \\
\hline Diesel & 117 & 79.1 & 1 & 85 & 13 & 14.0 \\
\hline Propane & 24 & 16.2 & 1 & 45 & 7 & 9.3 \\
\hline Natural gas & 3 & 2.0 & 1 & 5 & 3 & 2.0 \\
\hline Pumping cost (USD/ML) & 94 & - & 0.02 & 0.088 & 0.054 & 0.022 \\
\hline
\end{tabular}

Note: OFWS is On-Farm Water Storage; TWS is Tailwater Recovery System.

\subsubsection{Grower Perceptions and Attitudes}

The data collected on farmer perceptions and attitudes towards groundwater availability issues are summarized in Table 4. Less than one-third of growers observed a change in their wells' depth to water while over two-thirds of respondents indicated they perceived there was not a problem with the groundwater supply at their farm or in the state. A test of independence in these responses indicated that they had a statistically significant dependence: those who perceived there had been a change in their wells depth to water were more likely to believe there was a groundwater problem in their farm or at the state level.

The U.S. Geological Survey (USGS) has recently published a map of the Potentiometric Surface of the Mississippi River Valley Alluvial Aquifer for the Spring 2016 [25] that shows the location and gradient of the aquifer's cone of depression. A cross-tabulation of farmer perceptions and their location in the center of the cone of depression is presented in Table 5. A Pearson test of independence of the responses showed evidence that farmers located in the cone of depression were more likely to observe a change in their well levels and think there was a groundwater problem at the farm or state level. Half of those located in the center of the cone of depression believed there was a groundwater problem as opposed to 29 percent amongst those located outside that area. Similarly, forty-six percent of those 
in the cone of depression area observed a change in the depth-to-water in their wells while only 26 percent of those outside the area noticed such a change.

Table 4. Summary statistics of farmer perceptions and attitudes.

\begin{tabular}{lrrr}
\hline \multicolumn{4}{c}{ Thinks There Is a GW Problem } \\
\hline \multicolumn{1}{c}{ Frequency } & No & Yes & Total \\
\hline Well Depth to Water: & & & \\
No change & 60 & 24 & $\mathbf{8 4}$ \\
Increased & 9 & 11 & $\mathbf{2 0}$ \\
Decreased & 12 & 13 & $\mathbf{2 5}$ \\
Do not know & 16 & 2 & $\mathbf{1 8}$ \\
Refused & 1 & 0 & $\mathbf{1}$ \\
Total & $\mathbf{9 8}$ & $\mathbf{5 0}$ & $\mathbf{1 4 8}$ \\
\hline \multicolumn{4}{c}{ Percentage } \\
Change in Depth to Water: & Yes & Total \\
No/cannot tell & 51 & 17 & $\mathbf{6 8 . 9}$ \\
Changed & 14 & 16 & $\mathbf{3 0 . 4}$ \\
Refused & 1 & 0 & $\mathbf{0 . 7}$ \\
Total & $\mathbf{6 6 . 2}$ & $\mathbf{3 3 . 8}$ & $\mathbf{1 0 0}$ \\
\hline \multicolumn{4}{c}{ Pearson $\chi_{4}^{2}=\mathbf{1 3 . 4}$ with Pr $=\mathbf{0 . 0 0 9 .}$} \\
\hline \multicolumn{4}{c}{ Note: GW is Groundwater. }
\end{tabular}

Table 5. Aquifer "cone of depression" and farmer perceptions and attitudes.

\begin{tabular}{lrrr}
\hline \multicolumn{5}{c}{ Cone of Depression } \\
\hline \multicolumn{1}{c}{ Percentages } & No & Yes & Total \\
\hline Depth to Water: & 56 & 14 & 69 \\
No change & 20 & 11 & 31 \\
Changed & 76 & 24 & 100 \\
Total & \multicolumn{3}{c}{ Pearson $\chi_{1}^{2}=4.3$ with Pr $=\mathbf{0 . 0 3 8}$} \\
\hline \multicolumn{4}{c}{ Groundwater Problem: } \\
No & 54 & 12 & $\mathbf{6 6}$ \\
Yes & 22 & 12 & $\mathbf{3 4}$ \\
Total & $\mathbf{7 6}$ & $\mathbf{2 4}$ & $\mathbf{1 0 0}$ \\
\hline \multicolumn{4}{c}{ Pearson $\chi_{1}^{2}=\mathbf{5 . 6}$ with Pr $=\mathbf{0 . 0 1 8 .}$} \\
\hline
\end{tabular}

\subsection{Probit Regression Analysis}

The estimated models of practice adoption fit the data relatively well with pseudo- $R^{2}$ (McFadden's) ranging between 0.156 to 0.545 . Except for micro-irrigation (only five adopters), the conservation practices being analyzed had at least one factor with a statistically significant coefficient. The probit regression coefficients are detailed in Table 6 for all factors except cracking soils and income, which are detailed in Table 7.

Tailwater Recovery System (TWS) adoption was positively and significantly influenced by the farmers perception that a groundwater problem existed (GW prob.). The marginal effect $(d y / d x)$ indicated that a producer who becomes aware of the groundwater problems in the Delta area would be associated with a 25 percent higher likelihood of adopting TWS. The data indicated that farmers who do not use groundwater for irrigation have not adopted TWS.

For OFWS, the number of irrigated hectares under operation (Irr.area) was positively and significantly associated with the adoption of OFWS. The calculated marginal effect indicated that for an additional 40 hectares of farmed land, the probability of a farmer adopting OFWS was 0.8 
percent higher. The data indicated that farmers who did not use groundwater for irrigation have not adopted OFWS.

Table 6. Results from probit regressions (coefficients by income level in Table 7). Irr, Irrigation.

\begin{tabular}{|c|c|c|c|c|c|c|c|c|}
\hline & Irr. Area & GW Use & Rice & Years Farm & Educ. & GW Prob. & P. Cost & Cons.pr. \\
\hline $\begin{array}{l}\text { TWS } \\
\text { s.e. } \\
\text { dy/dx } \\
\text { McFadden's } R\end{array}$ & $\begin{array}{c}0.0001 \\
(0.0001) \\
0.00003 \\
2=0.228\end{array}$ & (a) & $\begin{array}{l}-0.398 \\
(0.435) \\
-0.115\end{array}$ & $\begin{array}{c}0.009 \\
(0.015) \\
0.003\end{array}$ & $\begin{array}{c}0.177 \\
(0.132) \\
0.051\end{array}$ & $\begin{array}{c}0.857 * * \\
(0.448) \\
0.25 * *\end{array}$ & $\begin{array}{c}0.464 \\
(1.052) \\
0.134\end{array}$ & $\begin{array}{c}0.691 \\
(0.588) \\
0.199\end{array}$ \\
\hline $\begin{array}{l}\text { OFWS } \\
\text { s.e. } \\
\text { dy/dx } \\
\text { McFadden's } R\end{array}$ & $\begin{array}{c}0.0003^{* *} \\
(0.005) \\
0.00008^{* * *} \\
2=0.324\end{array}$ & (a) & $\begin{array}{l}-0.007 \\
(0.507) \\
-0.002\end{array}$ & $\begin{array}{c}0.027 \\
(0.018) \\
0.006\end{array}$ & $\begin{array}{c}0.214 \\
(0.159) \\
0.052\end{array}$ & $\begin{array}{l}0.779 \\
(0.54) \\
0.189\end{array}$ & $\begin{array}{l}1.45 \\
(1.18) \\
0.353\end{array}$ & $\begin{array}{l}0.186 \\
(0.67) \\
0.045\end{array}$ \\
\hline $\begin{array}{l}\text { CHS } \\
\text { s.e. } \\
\text { dy/dx } \\
\text { McFadden's } R\end{array}$ & $\begin{array}{c}0.0002 * \\
(0.0001) \\
0.00005^{*} \\
2=0.271\end{array}$ & $\begin{array}{c}0.59 \\
(1.11) \\
0.16\end{array}$ & $\begin{array}{l}-0.176 \\
(0.49) \\
-0.048\end{array}$ & $\begin{array}{l}-0.01 \\
(0.015) \\
-0.003\end{array}$ & $\begin{array}{c}0.153 \\
(0.124) \\
0.041\end{array}$ & $\begin{array}{l}1.13^{* *} \\
(0.51) \\
0.30^{* *}\end{array}$ & $\begin{array}{c}-0.58 \\
(1.03) \\
-0.157\end{array}$ & $\begin{array}{l}-0.24 \\
(0.495) \\
-0.065\end{array}$ \\
\hline $\begin{array}{l}\text { Surge } \\
\text { s.e. } \\
\text { dy/dx } \\
\text { McFadden's } R\end{array}$ & $\begin{array}{c}0.00007 \\
(0.00011) \\
0.00002 \\
2=0.362\end{array}$ & (a) & $\begin{array}{l}-0.516 \\
(0.508) \\
-0.116\end{array}$ & $\begin{array}{l}-0.019 \\
(0.017) \\
-0.004\end{array}$ & $\begin{array}{c}0.258 \\
(0.151) \\
0.058^{* *}\end{array}$ & $\begin{array}{l}1.172^{*} \\
(0.601) \\
0.26^{* *}\end{array}$ & $\begin{array}{l}-2.462 \text { ** } \\
(1.23) \\
-0.55^{* *}\end{array}$ & $\begin{array}{l}0.735 \\
(0.76) \\
0.165\end{array}$ \\
\hline $\begin{array}{l}\text { SMS } \\
\text { s.e. } \\
\text { dy/dx } \\
\text { McFadden's } R\end{array}$ & $\begin{array}{c}0.0009 * * \\
(0.0003) \\
0.0002 * * * \\
2=0.545\end{array}$ & (a) & $\begin{array}{l}-2.72 \text { ** } \\
(0.94) \\
-0.5^{* * *}\end{array}$ & $\begin{array}{l}-0.016 \\
(0.019) \\
-0.003\end{array}$ & $\begin{array}{c}0.03 \\
(0.168) \\
0.005\end{array}$ & $\begin{array}{l}-0.81 \\
(0.9) \\
-0.15\end{array}$ & $\begin{array}{c}-1.1 \\
(1.31) \\
-0.204\end{array}$ & $\begin{array}{l}2.45^{* *} \\
(1.06) \\
0.45^{* *}\end{array}$ \\
\hline $\begin{array}{l}\text { Micro } \\
\text { s.e. } \\
\text { dy/dx } \\
\text { McFadden's } R\end{array}$ & $\begin{array}{l}-0.00003 \\
(0.0004) \\
2=0.464\end{array}$ & (a) & (b) & $\begin{array}{c}0.02 \\
(0.05) \\
0.0003\end{array}$ & $\begin{array}{c}0.47 \\
(0.63) \\
0.009\end{array}$ & (b) & $\begin{array}{l}-4.42 \\
(10.6) \\
-0.074\end{array}$ & (a) \\
\hline $\begin{array}{l}\text { Pivot } \\
\text { s.e. } \\
\text { dy/dx } \\
\text { McFadden's } R\end{array}$ & $\begin{array}{c}0.0001 \\
(0.0001) \\
0.00003 \\
2=0.156\end{array}$ & (a) & $\begin{array}{c}-0.622 \\
(0.471) \\
-0.18\end{array}$ & $\begin{array}{c}0.0005 \\
(0.015) \\
0.001\end{array}$ & $\begin{array}{c}0.24 * \\
(0.13) \\
0.068 * *\end{array}$ & $\begin{array}{c}-0.028 \\
(0.48) \\
-0.0087\end{array}$ & $\begin{array}{l}1.28 \\
(1.08) \\
0.363\end{array}$ & $\begin{array}{c}-0.29 \\
(0.58) \\
-0.083\end{array}$ \\
\hline $\begin{array}{l}\text { Timer } \\
\text { s.e. } \\
\text { dy/dx } \\
\text { McFadden's } R\end{array}$ & $\begin{array}{c}0.0003^{* *} \\
(0.0001) \\
0.00006^{* *} \\
2=0.355\end{array}$ & (a) & $\begin{array}{l}-0.84 \\
(0.52) \\
-0.2 *\end{array}$ & $\begin{array}{c}0.003 \\
(0.016) \\
0.001\end{array}$ & $\begin{array}{l}-0.14 \\
(0.13) \\
-0.034\end{array}$ & $\begin{array}{c}1.67^{* *} \\
(0.54) \\
0.41^{* * *}\end{array}$ & $\begin{array}{c}-0.43 \\
(1.23) \\
-0.1\end{array}$ & (b) \\
\hline $\begin{array}{l}\text { Flow-meter } \\
\text { s.e. } \\
\text { dy/dx } \\
\text { McFadden's } R\end{array}$ & $\begin{array}{c}0.0005^{* *} \\
(0.0003) \\
0.0001^{* *} \\
2=0.34\end{array}$ & $\begin{array}{l}0.181 \\
(1.15) \\
0.037\end{array}$ & $\begin{array}{l}-0.43 \\
(0.61) \\
-0.09\end{array}$ & $\begin{array}{c}0.017 \\
(0.016) \\
0.004\end{array}$ & $\begin{array}{c}0.167 \\
(0.143) \\
0.034\end{array}$ & $\begin{array}{c}0.932 \\
(0.67) \\
0.19\end{array}$ & $\begin{array}{l}-0.56 \\
(1.26) \\
-0.12\end{array}$ & $\begin{array}{c}0.33 \\
(0.56) \\
0.068\end{array}$ \\
\hline $\begin{array}{l}\text { Cover } \\
\text { s.e. } \\
\text { dy/dx } \\
\text { McFadden's } R\end{array}$ & $\begin{aligned} & 0.0001 \\
&(0.0001) \\
& 0.00003 \\
& 2= 0.21\end{aligned}$ & $\begin{array}{l}-0.76 \\
(1.55) \\
-0.21\end{array}$ & $\begin{array}{c}0.43 \\
(0.47) \\
0.12\end{array}$ & $\begin{array}{l}-0.04^{* *} \\
(0.018) \\
-0.011^{* *}\end{array}$ & $\begin{array}{c}0.068 \\
(0.125) \\
0.02\end{array}$ & $\begin{array}{l}-0.44 \\
(0.50) \\
-0.12\end{array}$ & $\begin{array}{c}-0.015 \\
(0.96) \\
-0.004\end{array}$ & $\begin{array}{c}0.78 \\
(0.59) \\
0.22\end{array}$ \\
\hline
\end{tabular}

Computerized Hole Selection (CHS) was positively and significantly associated with the number of irrigated hectares, the perception of the existence of a groundwater problem, and having an income between $\$ 100,000$ and $\$ 150,000$. The marginal effects indicated a 0.5 percent higher probability of CHS adoption for an additional 40 ha of land irrigated, and the probability of adoption increased by 30 percent when a farmer realized there was a groundwater problem at the farm or state level. 
Table 7. Results from probit regressions (continued) on "cracking" soils and income levels.

\begin{tabular}{|c|c|c|c|c|c|c|c|}
\hline & Cracking & $50 \mathrm{k}$ to $100 \mathrm{k}$ & $100 \mathrm{k}$ to $150 \mathrm{k}$ & $150 \mathrm{k}$ to $200 \mathrm{k}$ & $200 \mathrm{k}$ to $250 \mathrm{k}$ & $250 \mathrm{k}$ to $300 \mathrm{k}$ & $\geq 300 \mathrm{k}$ \\
\hline $\begin{array}{l}\text { TWS } \\
\text { s.e. } \\
\text { dy/dx }\end{array}$ & $\begin{array}{c}0.18 \\
(0.02) \\
0.005\end{array}$ & $\begin{array}{c}-0.49 \\
(0.6) \\
-0.14\end{array}$ & $\begin{array}{c}-0.5 \\
(0.637) \\
-0.144\end{array}$ & $\begin{array}{l}-1.195 \\
(1.02) \\
-0.345\end{array}$ & $\begin{array}{c}0.302 \\
(1.063) \\
0.087\end{array}$ & (dropped) & $\begin{array}{c}0.604 \\
(1.185) \\
0.174\end{array}$ \\
\hline $\begin{array}{l}\text { OFWS } \\
\text { s.e. } \\
\mathrm{dy} / \mathrm{dx}\end{array}$ & $\begin{array}{c}-0.008 \\
(0.03) \\
-0.002\end{array}$ & $\begin{array}{l}-1.021 \\
(0.684) \\
-0.248\end{array}$ & $\begin{array}{c}-0.7 \\
(0.676) \\
-0.17\end{array}$ & (dropped) & $\begin{array}{c}0.615 \\
(1.33) \\
0.15\end{array}$ & (dropped) & $\begin{array}{c}0.186 \\
(0.671) \\
0.045\end{array}$ \\
\hline $\begin{array}{l}\text { CHS } \\
\text { s.e. } \\
\text { dy/dx }\end{array}$ & $\begin{array}{l}0.035 \\
(0.02) \\
0.009\end{array}$ & $\begin{array}{c}0.611 \\
(0.625) \\
0.165\end{array}$ & $\begin{array}{c}1.325^{*} \\
(0.694) \\
0.358^{* *}\end{array}$ & $\begin{array}{c}0.59 \\
(0.878) \\
0.159\end{array}$ & $\begin{array}{l}0.273 \\
(1.05) \\
0.074\end{array}$ & $\begin{array}{l}0.613 \\
(1.25) \\
0.166\end{array}$ & $\begin{array}{c}1.33 \\
(1.24) \\
0.359\end{array}$ \\
\hline $\begin{array}{l}\text { Surge } \\
\text { s.e. } \\
\text { dy/dx }\end{array}$ & $\begin{array}{l}0.028 \\
(0.03) \\
0.006\end{array}$ & $\begin{array}{l}-1.26^{*} \\
(0.766) \\
-0.28^{*}\end{array}$ & $\begin{array}{l}-0.241 \\
(0.669) \\
-0.05\end{array}$ & $\begin{array}{c}0.66 \\
(0.963) \\
0.148\end{array}$ & (dropped) & (dropped) & $\begin{array}{c}1.44 \\
(1.165) \\
0.324\end{array}$ \\
\hline $\begin{array}{c}\text { SMS } \\
\text { s.e. } \\
\text { dy/dx }\end{array}$ & $\begin{array}{l}0.014 \\
(0.03) \\
0.003\end{array}$ & $\begin{array}{c}0.99 \\
(0.95) \\
0.183\end{array}$ & $\begin{array}{c}2.48^{* *} \\
(1.06) \\
0.458^{* *}\end{array}$ & $\begin{array}{l}-0.496 \\
(0.982) \\
-0.092\end{array}$ & $\begin{array}{c}0.258 \\
(1.091) \\
0.048\end{array}$ & $\begin{array}{c}-0.019 \\
(1.26) \\
-0.004\end{array}$ & $\begin{array}{c}-1.38 \\
(2.0) \\
-0.255\end{array}$ \\
\hline $\begin{array}{l}\text { Micro } \\
\text { s.e. } \\
\text { dy/dx }\end{array}$ & $\begin{array}{c}-0.052 \\
(0.06) \\
-0.001\end{array}$ & (dropped) & (dropped) & (dropped) & (dropped) & (dropped) & (dropped) \\
\hline $\begin{array}{l}\text { Pivot } \\
\text { s.e. } \\
\text { dy/dx }\end{array}$ & $\begin{array}{c}0.021 \\
(0.02) \\
0.06\end{array}$ & $\begin{array}{l}-0.45 \\
(0.64) \\
-0.13\end{array}$ & $\begin{array}{l}-0.49 \\
(0.64) \\
-0.14\end{array}$ & $\begin{array}{c}-0.365 \\
(0.927) \\
-0.1\end{array}$ & (b) & $\begin{array}{c}0.548 \\
(1.183) \\
0.156\end{array}$ & (a) \\
\hline $\begin{array}{l}\text { Timer } \\
\text { s.e. } \\
\text { dy/dx }\end{array}$ & $\begin{array}{c}0.046 \\
(0.029) \\
0.01\end{array}$ & $\begin{array}{l}-0.486 \\
(0.711) \\
-0.12\end{array}$ & $\begin{array}{c}-0.129 \\
(0.78) \\
-0.03\end{array}$ & $\begin{array}{c}0.421 \\
(0.9) \\
0.1\end{array}$ & $\begin{array}{c}-0.028 \\
(1.03) \\
-0.01\end{array}$ & (c) & (c) \\
\hline $\begin{array}{c}\text { Flow meter } \\
\text { s.e. } \\
\text { dy } / \mathrm{dx}\end{array}$ & $\begin{array}{c}0.03 \\
(0.03) \\
0.005\end{array}$ & $\begin{array}{l}-0.88 \\
(0.78) \\
-0.18\end{array}$ & $\begin{array}{c}0.09 \\
(0.87) \\
0.02\end{array}$ & $\begin{array}{l}-1.15 \\
(1.07) \\
-0.24\end{array}$ & (c) & (c) & (c) \\
\hline $\begin{array}{l}\text { Cover } \\
\text { s.e. } \\
\text { dy/dx }\end{array}$ & $\begin{array}{l}-0.003 \\
(0.019) \\
-0.001\end{array}$ & $\begin{array}{c}0.15 \\
(0.68) \\
0.041\end{array}$ & $\begin{array}{c}0.55 \\
(0.68) \\
0.155\end{array}$ & $\begin{array}{c}0.36 \\
(0.94) \\
0.1\end{array}$ & $\begin{array}{c}1.97^{*} \\
(1.06) \\
0.554^{* *}\end{array}$ & $\begin{array}{c}0.57 \\
(1.15) \\
0.16\end{array}$ & $\begin{array}{c}1.23 \\
(1.16) \\
0.34\end{array}$ \\
\hline
\end{tabular}

Note: base income is $\$ 50,000$ or less; $\mathrm{k}$ represents thousands of dollars. Standard errors are in parentheses. ${ }^{*}, * *$ : significant at $p<0.1, p<0.05$, respectively. (a) negative cases predict failure; (b) positive cases predict failure; (c) positive cases predict success.

The adoption of surge irrigation (surge) was positively and significantly associated with the perception of the existence of a groundwater problem and negatively by the pumping cost. The negative influence of the pumping cost variable was a departure from the hypothesized relations in the GAO report. Because this variable is a combination of various data with a fundamental rooting in the county of residence claimed by the farmer, there may be confounding of factors, the identification of which is beyond the scope of this study. However, the result was driven in part by the fact that nobody claiming to reside in the cone of depression (highest pumping cost) used surge irrigation. Surge irrigation is harder to manage in the cracking clays that are a common soil type in that area, but this effect did not appear statistically significant in this regression. The marginal effect calculations suggested that the probability of adoption of surge increased by 0.2 percent for an additional 40 hectares of irrigated land added to the operation, but an increase of one percent in the cost of pumping would decrease the adoption probability by 0.55 percent. The data indicated that farmers who do not use groundwater for irrigation have not adopted surge.

The use of SMS was significantly associated with irrigated area (positive at five percent), rice production (negative at five percent), participation in a conservation program (positive at five percent), and increasing income (from the baseline to the $\$ 100 \mathrm{k}$ to $\$ 150 \mathrm{k}$ income bracket, positive at five percent). The estimates suggested that an increase of 40 hectares in irrigated land would result in a two percent higher probability of adopting SMS; the choice of growing rice would reduce that probability by 50 percent, and the participation in a conservation program would add 45 percent to the SMS adoption 
probability. The data indicated that farmers who do not use groundwater for irrigation have not adopted SMS.

With respect to micro-irrigation, the probit regressions did not find statistically significant effects. This may be due in part to the relatively few respondents who claimed to practice it. For center pivot irrigation, however, there was enough variability to show a statistically significant and positive effect of the number of years of farmer formal education. For every additional year of formal education completed, the farmer was 0.68 percent more likely to adopt center pivot irrigation. The data indicated that farmers who do not use groundwater for irrigation have not adopted center pivot.

The adoption of a pump timer was positively and significantly associated with the number of irrigated hectares and the perception that a groundwater problem existed at the farm or state level. An additional 40 hectares or irrigated land was associated with a 0.6 percent higher probability of adoption, and the realization that a problem with groundwater stock existed in the state implied a 41 percent higher probability of employing a pump timer. All farmers in the sample with incomes above $\$ 250,000$ used pump timers.

Flow meter adoption was also positively and significantly associated with the number of irrigated hectares. An additional 40 hectares or irrigated land were associated with a one percent higher probability of adoption. All farmers in the sample with incomes above $\$ 200,000$ used flow meters.

Growing cover crops was negatively and significantly associated with farmer experience as represented by the number of years farming and positively associated with the $\$ 200,000$ to $\$ 250,000$ income bracket. An additional year of farming experience was associated with a 1.1 percent lower probability of growing cover crops. Since the agronomic benefits of cover crops payoff over a longer time-horizon, a farmer getting closer to retirement may be less eager to invest in a practice for which she/he will not see most of the benefits.

In terms of identifying factors that are associated with the adoption of conservation practices, the results indicated the following: irrigated area (positive), GW use (positive), rice (negative), years farming (negative), education years (positive), perception of GW problem (positive), pumping costs (negative), conservation program participation (positive), and income (positive). These results confirmed the stated hypotheses with respect to factor association except for the effect of pumping cost, which was expected to have a positive association with the adoption of conservation practices. It is not clear from the data what drives this result, which is limited to the adoption of surge irrigation only and does not appear statistically significant for other practices.

\section{Discussion}

Promoting the adoption of water conservation practices in irrigated agriculture has been a principal initiative to slow down the decline of the Mississippi River Valley Alluvial Aquifer (MRVAA). Ongoing agronomic research from scientists at Mississippi State University's Delta Research and Extension Center (DREC) and the USDA Agricultural Research Service in Stoneville, MS, continue to show the potential for these practices to reduce water use while maintaining farm yield and revenue levels. The Mississippi Department of Environmental Quality and the Yazoo Mississippi Delta Joint Water Management District require the use of a minimum number of these practices to issue groundwater well drilling and use permits in the area. Grower associations such as the Delta Farmers Advocating Resource Management (F.A.R.M.) sponsor and promote the use of these practices among their members. Financial and technical assistance from USDA Natural Resource Conservation Service (NRCS) is geared towards minimizing farmer risk exposure associated with the implementation of these conservation practices. However, little is known about the farmer factors that drive their decision to adopt any given conservation practice. This article provides insights that help identify and understand the determinants of conservation practice adoption in the Delta region in Mississippi.

The regression analyses indicated that no single factor consistently predicted the adoption of every conservation practice, but many factors influence a farmer's decision to adopt a given practice. The size of the farming operation is an important factor in deciding the adoption of agricultural 
practices in general. Indeed, it is the factor with the most statistically significant coefficients (positive) in the regression analyses. From an economic perspective, this may be attributed to the fact that practices that are marginally beneficial on a per hectare basis may not be worth the managerial cost to small operations, but could add-up to significant economies of scale for larger operations in which fixed and overhead costs associated with a practice can be spread over more hectares.

Results from the 2016 Mississippi Irrigation Survey indicated that groundwater is a source for irrigation for almost 93 percent of growers in the sample. Yet, only a third of the growers think there is a groundwater problem at the farm or state level. The analysis presented suggests that this lack of awareness is significantly related to whether the growers observe a change in the depth to water in their wells or not.

Perception of the existence of a GW problem at the farm or state level was the second most important factor identified. This is an encouraging finding because the results show a strong influence of this variable on the probability of the adoption of several adoption practices and because this is, essentially, an awareness issue. Perception of water quantity issues in regions of high rainfall can be difficult to overcome. This suggests that additional incentives are necessary to bring those who do not perceive a problem to the realization that it actually exists.

Increasing producer awareness is a task that fits, for example, the mission of university extension services, which can aid the communications efforts of federal and state research and regulatory entities in that regard. Regulatory agencies and universities can work together to have a consistent message regarding the projection of groundwater in the state and to increase grower awareness of the issue with a focus on county-based expected changes in wells' depth-to-water distances. However, such efforts have been carried out by these organizations, which suggests there is a need for an additional signal to help convince farmers of the seriousness of the situation.

At nearly 70 percent of respondents, this sample far surpasses the national average of 30 percent flow-meter use [31]. However, only 10 to 15 percent of permittees report individual water-use every year. There is promising evidence from areas with mandatory water use reporting that producers become better informed and more concerned with the health of the aquifer.

For example, growers near Sheridan county in Kansas widely supported a self-imposed Local Enhancement Management Area to create a five year allocation of groundwater that resulted in a 26 percent reduction in water use [32]. A similar case where the threat of regulation from the state level induced irrigators to form the Groundwater Subdistrict No. 1 in the San Luis Valley of Colorado and "formulate a homegrown governance response" that reduced water use by 33 percent in the district [33].

The survey results in our study indicated that farmers may require stronger signals that the aquifer problem is real and important. Furthermore, the experience documented in the aforementioned studies suggested that aquifer problem awareness, resulting largely from individual water use monitoring, and the threat of top-down regulation can induce more active farmer participation in water conservation.

Although participation in conservation programs was a statistically significant factor for only one of the practices (SMS), Figure 1 shows how NRCS expenditures [34] and practice adoption in the region track similar time trends. In particular, the rate of adoption of CHS, SMS, and surge starting in 2009 are noteworthy. This suggests there is an effect of NRCS technical and financial assistance in terms of adoption. However, perhaps due to insufficient data, this association cannot be validated empirically in this study.

These results can inform policy makers, regulatory entities, university extension services, and producers about the salient aspects of conservation practice adoption in Mississippi. Conservation agencies can use the insights in this study to better target their incentive programs, for instance focusing on incentivizing relatively young farmers to adopt practices with long-term benefits such as cover crops. Similarly, further research, extension, and incentives are necessary to devise incentives and training 
to facilitate practice adoption by smaller farms. Lastly, periodic surveys ( $2-5$ year intervals) may be necessary to track trends and assess the effectiveness of conservation practice adoption programs.

Our results are largely consistent with the most recent literature [4,6,22]; see Table 8 for a comparison. The GAO report in particular describes policy options at the federal level including their benefits and challenges. With respect to irrigation technology, it recommends that policy makers promote: (1) the use of more efficient irrigation technology and practices, in conjunction with appropriate agreements to use the technology and practices to conserve water; and (2) the use of precision agriculture technologies, in conjunction with appropriate agreements to use the precision agriculture technologies to conserve water. These recommendations are consistent with the ongoing efforts mentioned above, and this study lends empirical validity to the recommendations for the case of Mississippi.

\section{Adoption of Conservation Practices in MS}

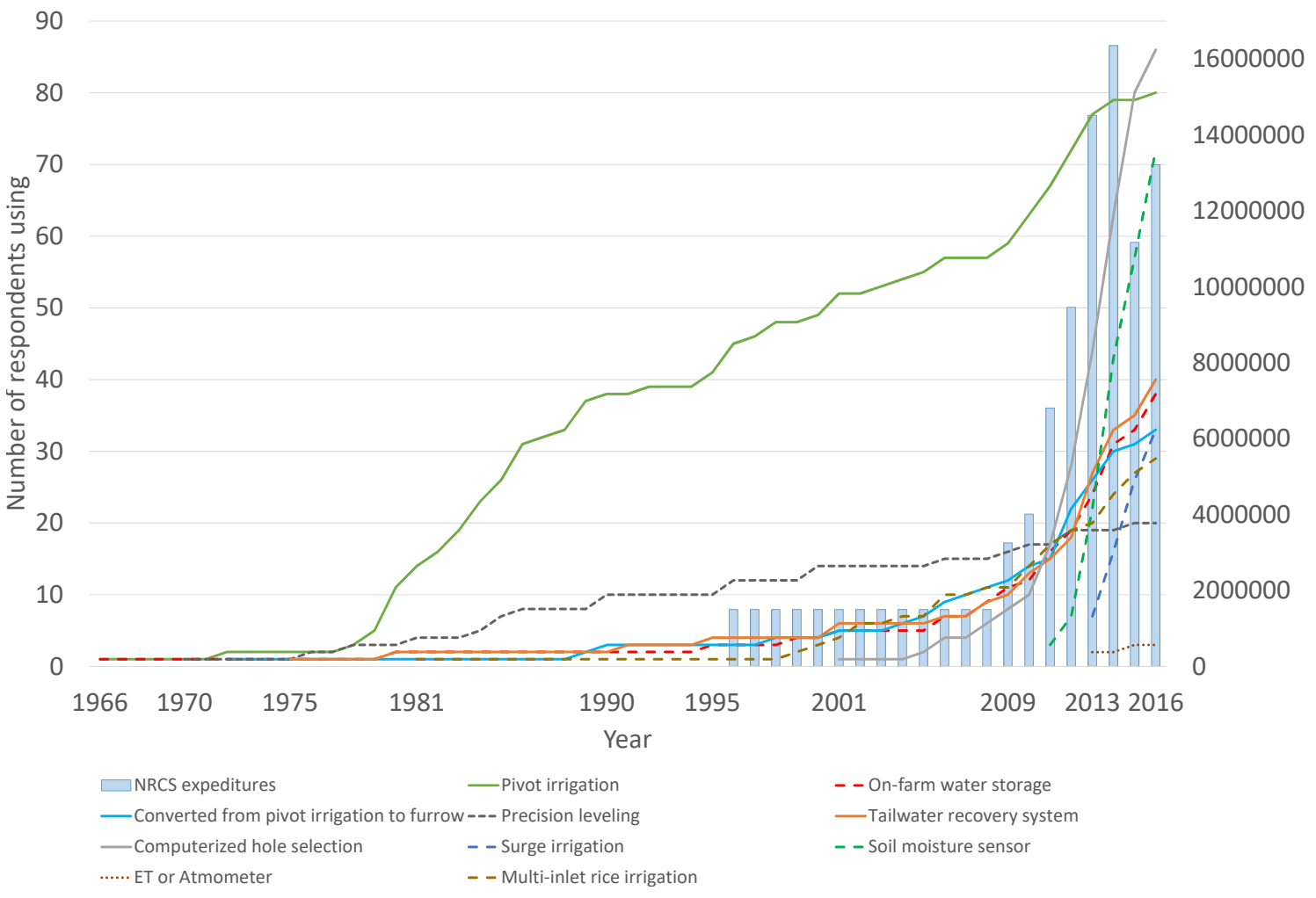

Figure 1. Timeline of the adoption of conservation practices and USDA-NRCS EQIP expenditures in the MS Delta area.

Table 8. Impact of conservation practice adoption factors compared to existing literature.

\begin{tabular}{|c|c|c|c|c|}
\hline Factor & Results & $\begin{array}{l}\text { Nian et al. } \\
\text { Morris (2020) }\end{array}$ & $\begin{array}{c}\text { Prokopy et al. } \\
\text { (2019) }\end{array}$ & $\begin{array}{l}\text { Pearsons and } \\
\text { (2019) }\end{array}$ \\
\hline Irrigated area & Pos & Pos & Pos & Pos \\
\hline GW use & Pos & Pos & Pos & \\
\hline Rice farming & Neg & & Mix & \\
\hline Years farming & Neg & $\mathrm{Neg}$ & Neg & $\mathrm{Neg}$ \\
\hline Education & Pos & & Mix & Pos \\
\hline Perceives GW problem & Pos & Pos & Pos & Pos \\
\hline Pumping cost & Neg & & Pos & Neg \\
\hline Participation in conservation programs & Pos & Pos & Pos & Pos \\
\hline Cracking soils & Mix & & & Neg \\
\hline Farmer income & Mix & Pos & Pos & Pos \\
\hline
\end{tabular}

Note: Pos denotes a Positive influence of the factor on adoption; Neg denotes a Negative influence of the factor on adoption; Mix denotes Mixed or undetermined influence of the factor on adoption. 
The main limitation of this study is the small sample relative to the number of practices and factors being considered. This limitation determined the choice of probit regression models rather than multivariate and sequential modeling. There is evidence that practices, especially add-ons to furrow irrigation, are adopted in bundles. This feature is not incorporated in this study and constitutes a promising avenue for future research.

Author Contributions: Conceptualization, N.Q.-A. and D.M.G.; methodology, N.Q.-A.; software, N.Q.-A.; validation, D.M.G. and L.J.K.; formal analysis, N.Q.-A.; investigation, L.J.K. and C.G.H.; resources, L.J.K., C.G.H., and T.C.; data curation, N.Q.-A.; writing, original draft preparation, N.Q.-A.; writing, review and editing, N.Q.-A., D.M.G., and L.J.K.; funding acquisition, L.J.K., C.G.H., and T.C. All authors read and agreed to the published version of the manuscript.

Funding: This publication is a contribution of the National Center for Alluvial Aquifer Research and the Mississippi Agricultural and Forestry Experiment Station. This material is based on work that was funded jointly by the Agricultural Research Service, United States Department of Agriculture, under Cooperative Agreement Number 58-6001-7-001. Financial support for the 2016 Mississippi Survey of Irrigators came from the Mississippi Soybean Board, Mid-South Soybean Board, and United Soybean Board.

Acknowledgments: The authors acknowledge and thank Paul Rodrigue, USDA-NRCS Supervisory Engineer Area 4, for helpful advice and regional NRCS expenditure data. Additionally, the authors are grateful for financial support for the survey from the Mississippi Soybean Board, Mid-South Soybean Board, and United Soybean Board.

Conflicts of Interest: The authors declare no conflict of interest.

\section{Abbreviations}

The following abbreviations are used in this manuscript:

$\begin{array}{ll}\text { AAWEP } & \text { Acceptable Agricultural Water Efficiency Practices } \\ \text { AWEP } & \text { Agricultural Water Enhancement Program } \\ \text { ARS } & \text { USDA Agricultural Research Service } \\ \text { CHS } & \text { Computerized hole selection } \\ \text { CRP } & \text { Conservation Reserve Program } \\ \text { DREC } & \text { Mississippi State University Delta Research and Extension Center } \\ \text { EIA } & \text { U.S. Energy Information Administration } \\ \text { EQIP } & \text { NRCS Environmental Quality Incentives Program } \\ \text { F.A.R.M. } & \text { Delta Farmers Advocating Resource Management } \\ \text { FSA } & \text { Farm Service Agency } \\ \text { GAO } & \text { Government Accountability Office } \\ \text { GW } & \text { Groundwater } \\ \text { MRVAA } & \text { Mississippi River Valley Alluvial Aquifer } \\ \text { NRCS } & \text { USDA Natural Resources Conservation Service } \\ \text { OFWS } & \text { On-Farm Water Storage } \\ \text { RCPP } & \text { Regional Conservation Partnership Program } \\ \text { SMS } & \text { Soil Moisture Sensors } \\ \text { TWS } & \text { Tailwater Recovery System } \\ \text { USACE } & \text { U.S. Army Corps of Engineers } \\ \text { USDA } & \text { U.S. Department of Agriculture } \\ \text { WRP } & \text { Wetlands Reserve Program }\end{array}$

\section{Appendix A. Conservation Programs in Mississippi}

The Delta region in Mississippi has a diversity of habitats in which urban, agricultural, and wildlife habitat landscapes coexist. Growers and landowners in the area actively seek guidance in attaining land and water resource stewardship. Hunting and fishing clubs are among the highest priced memberships in the areas. Agricultural land and water projects often include wildlife habitat enhancing features that further increase the value of such clubs. The National Wildlife Federation work in the area focuses on protecting and restoring healthy rivers and estuaries, conserving wetlands, springs, and aquifers, and protecting wildlife habitats. These goals overlap with producer interests 
and are prominent features in existing conservation programs in the area. Table A1 contains a list and brief description of the conservation programs in which survey respondents claimed to participate.

Table A1. List and brief description of the conservation programs in which survey respondents claimed to participate.

\begin{tabular}{|c|c|c|}
\hline Program & Sponsor & Description \\
\hline AWEP & NRCS & $\begin{array}{l}\text { Agricultural Water Enhancement Program is a conservation initiative } \\
\text { that provides financial and technical assistance to agricultural } \\
\text { producers to implement agricultural water enhancement activities on } \\
\text { agricultural land for the purposes of conserving surface and groundwater } \\
\text { and improving water quality. }\end{array}$ \\
\hline CRP & FSA & $\begin{array}{l}\text { Conservation Reserve Program is a land conservation program to } \\
\text { remove environmentally sensitive land from agricultural production } \\
\text { and plant species that will improve environmental health and quality. }\end{array}$ \\
\hline CSP & NRCS & $\begin{array}{l}\text { Conservation Stewardship Program participants earn performance-based } \\
\text { CSP payments: higher payment to higher performance. }\end{array}$ \\
\hline Delta F.A.R.M. & $\begin{array}{l}\text { Public-private } \\
\text { partnership }\end{array}$ & $\begin{array}{l}\text { Farmers Advocating Resource Management is an association of growers } \\
\text { and landowners that strive to implement recognized agricultural } \\
\text { practices, which will conserve, restore, and enhance the environment. }\end{array}$ \\
\hline EQIP & NRCS & $\begin{array}{l}\text { Environmental Quality Incentives Program provides incentive payments } \\
\text { and cost-sharing for conservation practice adoption. }\end{array}$ \\
\hline $\mathrm{RCPP}$ & NRCS & $\begin{array}{l}\text { Regional Conservation Partnership Program promotes coordination of } \\
\text { NRCS conservation activities with partners that offer value-added } \\
\text { contributions to expand their collective ability to address on-farm, } \\
\text { watershed, and regional natural resource concerns. }\end{array}$ \\
\hline Rice stewardship & $\begin{array}{l}\text { Public-private } \\
\text { partnerships }\end{array}$ & $\begin{array}{l}\text { USA Rice-Ducks Unlimited Rice Stewardship Partnership provides } \\
\text { financial assistance for conserving water and wildlife in ricelands. }\end{array}$ \\
\hline Soil erosion & Unspecified & Unspecified \\
\hline Unspecified & USACE & $\begin{array}{l}\text { The U.S. Army Corps of Engineers may enroll farmers adjacent to their } \\
\text { projects as part of environmental or habitat enhancement features. }\end{array}$ \\
\hline WRP & NRCS & $\begin{array}{l}\text { Wetlands Reserve Program offers landowners the opportunity to } \\
\text { protect, restore, and enhance wetlands on their property. }\end{array}$ \\
\hline
\end{tabular}

\section{References}

1. Christy, D. (Yazoo Mississippi Delta Joint Water Management District, Mississippi State University, Starkville, MS, USA). Personal communication, 2014.

2. Kebede, H.; Fisher, D.K.; Sui, R.; Reddy, K.N. Irrigation methods and scheduling in the Delta region of Mississippi: Current status and strategies to improve irrigation efficiency. Am. J. Plant Sci. 2014, 5, 2917. [CrossRef]

3. Barlow, J.R.; Clark, B.R. Simulation of Water-Use Conservation Scenarios for the Mississippi Delta Using an Existing Regional Groundwater Flow Model; U.S. Geological Survey Scientific Investigations Report 2011-5019; US Department of the Interior, US Geological Survey: Washington, DC, USA, 2011; 14p.

4. Nian, Y.; Huang, Q.; Kovacs, K.F.; Henry, C.; Krutz, J. Water Management Practices: Use Patterns, Related Factors and Correlations with Irrigated Acres. Water Resour. Res. 2020, 56, e2019WR025360. [CrossRef]

5. Balogh, P.; Bujdos, Á.; Czibere, I.; Fodor, L.; Gabnai, Z.; Kovách, I.; Nagy, J.; Bai, A. Main Motivational Factors of Farmers Adopting Precision Farming in Hungary. Agronomy 2020, 10, 610. [CrossRef]

6. Persons, T.M.; Morris, S.D. Irrigated Agriculture: Technologies, Practices, and Implications for Water Scarcity. In Report to Congressional Requesters, Technology Assessment; GAO-20-128SP; U.S. Government Accountability Office: Washington, DC, USA, 2019.

7. Bryant, C.; Krutz, L.; Falconer, L.; Irby, J.; Henry, C.; Pringle, H.; Henry, M.; Roach, D.; Pickelmann, D.; Atwill, R.; et al. Irrigation water management practices that reduce water requirements for Mid-South furrow-irrigated soybean. Crop Forage Turfgrass Manag. 2017, 3, 1-7. [CrossRef] 
8. Henry, W.B.; Krutz, L.J. Water in agriculture: Improving corn production practices to minimize climate risk and optimize profitability. Curr. Clim. Chang. Rep. 2016, 2, 49-54. [CrossRef]

9. Wood, C.; Krutz, L.; Falconer, L.; Pringle, H.; Henry, B.; Irby, T.; Orlowski, J.; Bryant, C.; Boykin, D.; Atwill, R.; et al. Surge irrigation reduces irrigation requirements for soybean on smectitic clay-textured soils. Crop Forage Turfgrass Manag. 2017, 3, 1-6. [CrossRef]

10. Spencer, G.; Krutz, L.; Falconer, L.; Henry, W.; Henry, C.; Larson, E.; Pringle, H.; Bryant, C.; Atwill, R. Irrigation Water Management Technologies for Furrow-Irrigated Corn that Decrease Water Use and Improve Yield and On-Farm Profitability. Crop Forage Turfgrass Manag. 2019, 5, 1-8. [CrossRef]

11. Carey, J.M.; Zilberman, D. A model of investment under uncertainty: modern irrigation technology and emerging markets in water. Am. J. Agric. Econ. 2002, 84, 171-183. [CrossRef]

12. Yazoo Mississippi Delta Joint Water Management District, Permit Application. Available online: https: / / www.ymd.org/permitting (accessed on 15 June 2020).

13. Krutz, L. Utilizing Moisture Sensors to Increase Irrigation Efficiency; Mississippi State University Extension Service: Starkville, MS, USA, 2016.

14. Krutz, L. Pipe Planner: The Foundation Water Management Practice for Furrow Irrigated Systems; Mississippi State University Extension Service: Starkville, MS, USA, 2016.

15. Roach, D. Flow Meters Available at County Extension Offices; Mississippi State University Extension Service: Starkville, MS, USA, 2018.

16. Krutz, L. Surge Valves Increase Application Efficiency; Mississippi State University Extension Service: Starkville, MS, USA, 2016.

17. Tagert, M.L.; Paz, J.; Reginelli, D. On-Farm Water Storage Systems and Surface Water for Irrigation; Mississippi State University Extension Service: Starkville, MS, USA, 2018.

18. Zotarelli, L.; Fraisse, C.; Dourte, D. Agricultural Management Options for Climate Variability and Change: Microirrigation; EDIS UF/IFAS (HS1203); University of Florida: Gainesville, FL, USA, 2015.

19. Coblentz, B.A. Pivot Irrigation, Not Furrows, Is Most Economical for Delta; Mississippi State University Extension Service: Starkville, MS, USA, 2014.

20. Burdine, B. Cover Crops: Benefits and Limitations; Mississippi State University Extension Service: Starkville, MS, USA, 2019.

21. Coblentz, B.A. Cover Crops Present Challenges, Advantages; Mississippi State University Extension Service: Starkville, MS, USA, 2018.

22. Prokopy, L.S.; Floress, K.; Arbuckle, J.G.; Church, S.P.; Eanes, F.; Gao, Y.; Gramig, B.M.; Ranjan, P.; Singh, A.S. Adoption of agricultural conservation practices in the United States: Evidence from 35 years of quantitative literature. J. Soil Water Conserv. 2019, 74, 520-534. [CrossRef]

23. Edwards, J.F. Crop Irrigation Survey; Final Report; Mississippi State University, Social Science Research Center, Survey Research Laboratory: Starkville, MS, USA, 2016; unpublished.

24. Rogers, D.H.; Alam, M. Comparing Irrigation Energy Costs; Agricultural Experiment Station and Cooperative Extension Service, Kansas State University: Manhattan, KS, USA, 2006; MF-2360.

25. McGuire, V.L.; Seanor, R.C.; Asquith, W.H.; Kress, W.H.; Strauch, K.R. Potentiometric surface of the Mississippi River Valley Alluvial Aquifer, Spring 2016: U.S. Geological Survey Scientific Investigations Map 3439; Technical Report; US Geological Survey: Washington, DC, USA, 2019; 14p, 5 sheets. [CrossRef]

26. USDA-NRCS. Soil Survey Staff, Natural Resources Conservation Service, United States Department of Agriculture. In Soil Survey Geographic (SSURGO) Database for Sunflower County, Mississippi; USDA-NRCS: Washington, DC, USA, 2010.

27. Maddala, G.S. Limited-Dependent and Qualitative Variables in Econometrics; Cambridge University Press: Cambridge, UK, 1986; Volume 3.

28. Pfeiffer, L.; Lin, C.Y.C. Does efficient irrigation technology lead to reduced groundwater extraction? Empirical evidence. J. Environ. Econ. Manag. 2014, 67, 189-208.

29. Fenichel, E.P.; Abbott, J.K.; Bayham, J.; Boone, W.; Haacker, E.M.; Pfeiffer, L. Measuring the value of groundwater and other forms of natural capital. Proc. Nat. Acad. Sci. USA 2016, 113, 2382-2387. [CrossRef] [PubMed]

30. Hassanli, A.M.; Ebrahimizadeh, M.A.; Beecham, S. The effects of irrigation methods with effluent and irrigation scheduling on water use efficiency and corn yields in an arid region. Agric. Water Manag. 2009, 96, 93-99. [CrossRef] 
31. USDA. Irrigation: Results from the 2013 Farm and Ranch Irrigation Survey; Census Agricultyre Highlights ACH12-16; USDA: Washington, DC, USA, 2014.

32. Drysdale, K.M.; Hendricks, N.P. Adaptation to an irrigation water restriction imposed through local governance. J. Environ. Econ. Manag. 2018, 91, 150-165.

33. Smith, S.M.; Andersson, K.; Cody, K.C.; Cox, M.; Ficklin, D. Responding to a groundwater crisis: The effects of self-imposed economic incentives. J. Assoc. Environ. Resour. Econ. 2017, 4, 985-1023. [CrossRef]

34. USDA-NRCS. The PROTRACTS Database, Mississippi; USDA-NRCS: Washington, DC, USA, 2019.

(C) 2020 by the authors. Licensee MDPI, Basel, Switzerland. This article is an open access article distributed under the terms and conditions of the Creative Commons Attribution (CC BY) license (http:/ / creativecommons.org/licenses/by/4.0/). 